INTERNATIONAL FOOD POLICY

RESEARCH INSTITUTE

sustainable solutions for ending hunger and poverty

IFPRI ${ }^{\circledR}$ A member of the CGIAR consortium

IFPRI Discussion Paper 01214

October 2012

\title{
An Overview of Chinese Agricultural and Rural Engagement in Tanzania
}

Deborah Bräutigam

Xiaoyang Tang

Development Strategy and Governance Division 


\section{INTERNATIONAL FOOD POLICY RESEARCH INSTITUTE}

The International Food Policy Research Institute (IFPRI) was established in 1975 to identify and analyze national and international strategies and policies for meeting the food needs of the developing world on a sustainable basis, with particular emphasis on low-income countries and on the poorer groups in those countries. IFPRI is a member of the CGIAR Consortium.

\section{PARTNERS AND CONTRIBUTORS}

IFPRI gratefully acknowledges the generous unrestricted funding from Australia, Canada, China, Denmark, Finland, France, Germany, India, Ireland, Italy, Japan, the Netherlands, Norway, the Philippines, South Africa, Sweden, Switzerland, the United Kingdom, the United States, and the World Bank.

\section{AUTHORS}

Deborah Bräutigam, Johns Hopkins University

Professor and Director, School of Advanced International Studies

dbrautigam@jhu.edu

Xiaoyang Tang, International Food Policy Research Institute

Senior Research Assistant, Development Strategy and Governance Division

Tsinghua University

Assistant Professor, Department of International Relations

IFPRI Discussion Papers contain preliminary material and research results. They have been peer reviewed, but have not been subject to a formal external review via IFPRI's Publications Review Committee. They are circulated in order to stimulate discussion and critical comment; any opinions expressed are those of the author(s) and do not necessarily reflect the policies or opinions of IFPRI.

Copyright 2012 International Food Policy Research Institute. All rights reserved. Sections of this material may be reproduced for personal and not-for-profit use without the express written permission of but with acknowledgment to IFPRI. To reproduce the material contained herein for profit or commercial use requires express written permission. To obtain permission, contact the Communications Division at ifpri-copyright@cgiar.org. 


\section{Contents}

Abstract $\quad$ V

Acknowledgments $\quad$ vi

1. Introduction 1

2. China and Tanzania Historical Background, 1964-1999 4

3. China's Official Agriculture and Rural Aid Projects, 1999-2011 9

4. Other Recent Agricultural/Rural Cooperation, 1999-2011 13

5. Chinese Foreign Direct Investment in Agriculture and Rural Development, 1999-2011 17

References $\quad 21$ 
Figure

2.1 - Mbarali rice farm yield (tons/ha) 


\begin{abstract}
The recent expansion of Chinese economic engagement in Africa is often poorly documented and not well understood. This paper is the second in an IFPRI-sponsored effort to better understand Chinese engagement in Africa's agricultural sector. A clearer picture of Chinese activities in agriculture is important as a foundation for Africans and their development partners to more fruitfully engage with an increasingly important actor. Chinese engagement in agriculture and rural development in Tanzania is long-standing. Changes in this engagement reflect the changes in China's engagement in Africa more generally. This overview paper explores China's engagement in historical perspective, focusing on foreign aid, other official engagement, and investment by Chinese firms between 1964 and 2011.
\end{abstract}

Keywords: China and Africa; China and Tanzania; agribusiness; foreign aid and agriculture 


\section{ACKNOWLEDGMENTS}

The authors thank Nicholas Smith for his excellent assistance with this research. 


\section{INTRODUCTION}

Chinese engagement in agriculture and rural development in Tanzania is long-standing and covers multiple activities. Although China was very active as a donor in the 1960s and 1970s, its engagement slowed in the 1980s, shifting away from new projects into efforts to boost the sustainability of past projects. In the 1990s, the focus changed to incorporate far more commercial and investment activities. Yet few Chinese investors have made commitments to invest in agricultural activities in Tanzania. As one Chinese economic counselor said in 2008, "Agriculture is risky here. It is hard to have win-win" (Pers. comm. 2008). ${ }^{1}$ This paper documents the full range of Chinese agricultural and rural development activities in Tanzania, both historical and contemporary. Its primary purpose is to serve as background for other researchers: Tanzanians and foreigners.

Researchers from IFPRI visited Tanzania (Dar es Salaam, Kilosa and Dakawa in Morogoro Region, and Zanzibar) between September 17 and 30, 2011, to conduct a scoping study of Chinese engagement in agriculture and rural development. The researchers conducted more than 30 interviews, primarily with Chinese and Tanzanian officials and businesses, and with several knowledgeable foreign experts. We also obtained census data on all approvals of specific Chinese foreign investment activities in agriculture and agribusiness from the national investment authorities to locate Chinese investors. The report also draws on earlier visits by IFPRI researchers to Tanzania as well as published and unpublished documents and secondary material. ${ }^{2}$

\section{China and Africa: Frameworks for Engagement in Agriculture}

China's success in feeding a fifth of the world's population with only 8 percent of its arable land is well known. Thousands of years of intensification of farming in much of the country have led to very high yields per hectare of land. China's hybrid rice pioneer Yuan Longping, for example, has just produced a variety that yields 13.9 metric tons per hectare $(\mathrm{mt} / \mathrm{ha})$ under trial conditions. ${ }^{3}$ Labor-intensive cultivation practices such as the transplantation of irrigated paddy rice are common. Yet China also has arid grasslands and pastoral communities that bear some resemblance to the rural areas of Tanzania.

China's policy on engagement in agriculture in Africa can be seen in its January 2006 document China's African Policy and in the action plans resulting from several rounds of high-level meetings under the Forum on China-Africa Cooperation (FOCAC). According to China's African Policy (2006),

Focus will be laid on the cooperation in land development, agricultural plantation, breeding technologies, food security, agricultural machinery and the processing of agricultural and side-line products. China will intensify cooperation in agricultural technology, organize training courses of practical agricultural technologies, carry out experimental and demonstrative agricultural technology projects in Africa and speed up the formulation of China-Africa Agricultural Cooperation Program. (Part IV, 2 [4]) ${ }^{4}$

Two recent action plans following ministerial-level meetings of FOCAC have emphasized agricultural cooperation. (As with other summits, action plans are developed beforehand by working groups.) During the 2006 Beijing FOCAC summit, the two sides - China on one side and African governments on the other-pledged to "intensify their exchanges and cooperation in farming, animal husbandry, irrigation, fishery, agricultural machinery, processing of agricultural produce, sanitary and phytosanitary measures, food safety and epidemic control" (Section III, 3.1). In 2009, China pledged to

\footnotetext{
${ }^{1}$ Chinese official, interview, Dar es Salaam, January 8, 2008.

${ }^{2}$ These earlier visits were not under IFPRI auspices. Deborah Bräutigam visited Tanzania in 2008 and Xiaoyang Tang visited in 2009.

${ }^{3}$ All tons referred to in the paper are metric tons.

${ }^{4}$ The China-Africa Agricultural Cooperation Forum has involved a series of high-level meetings under the FOCAC umbrella (www.focac.org/eng/dsjbzjhy/t725504.htm). Beijing has signed agriculture, husbandry, and fisheries cooperation agreements with Tanzania and Ethiopia, as well as a dozen or so other African countries.
} 
enhance cooperation in "agricultural infrastructure, grain production, breeding industry, exchanges and transfer of practical agricultural technologies, and in processing, storage and transportation of agricultural products" (Section 4.1.3).

China's agricultural engagement in Africa involves trade, investment, foreign aid, and government-sponsored bilateral cooperation based on mutual benefit. ${ }^{5}$ The Ministry of Commerce (MOFCOM) is a central actor. China's foreign aid program is run out of MOFCOM's Department of Foreign Aid, while investment and some areas of cooperation are promoted by MOFCOM's Department for Outward Investment and Economic Cooperation. For agricultural aid, MOFCOM coordinates with the International Economic Cooperation Center of the Ministry of Agriculture and sometimes the equivalent department in the Ministry of Science and Technology.

In the 1960s and 1970s, China's agricultural aid in Africa emphasized large state farms. This changed in the 1980s, when small-scale projects in support of smallholder farmers were favored. ${ }^{6}$ Recent agriculturally relevant foreign aid includes the dispatch of 100 senior agricultural experts to Africa for a year of technical assistance (most countries received two or three experts); short-term training in China; and the establishment of 20 agrotechnology demonstration centers across the continent. In addition to these standard programs, some African countries have received other agricultural assistance, such as vocational training, South-South cooperation with the Food and Agriculture Organization of the United Nations (FAO), and rural roads.

Together with the Ministry of Agriculture, MOFCOM originally conceived of its grant-financed agrotechnology demonstration centers as an experiment. Chinese companies and institutes, selected via a competitive tender system in China, would build the centers, and the Chinese aid budget would pay for equipment and Chinese personnel to help run them for three years. During that time, the Chinese companies and institutes would seek out income-generation activities that would enable the centers to fund their own revenue streams. They would also use their time at the centers as a platform to seek other commercial opportunities in the country. This experimental approach is an example of foreign aid coupled with mutually beneficial cooperation. It is based on a responsibility system that has been widely practiced in many of China's own domestic government centers and agencies.

Other Chinese engagement in agriculture involves the China Development Bank (CDB) and the China Export Import Bank (Eximbank), both of which provide commercial development finance and export credits; the China Eximbank also provides concessional foreign aid loans. The CDB is the parent organization of the China-Africa Development Fund, which has signed a strategic agreement with the China State Farm Agribusiness Corporation to set up a joint company to make agricultural investments. In Africa, this has not yet resulted in much beyond the transfer of some of the corporation's existing investments (mainly, but not only, former aid projects) to the new joint venture. China also has provided zero-tariff entry for a large number of agricultural commodities and processed goods (cotton yarn, sisal fiber, finished leather, and so on) from Africa's low-income countries.

China's strategy for agricultural engagement abroad has a long-term perspective. China believes that aid, investment, and other forms of cooperation should be used to increase food and agricultural output globally. The Chinese are fully aware of the sensitivities of large-scale agricultural investment in Africa. Although Chinese companies have investigated a number of potential projects, generating many media stories, there do not appear to be any documented cases of Chinese companies actually implementing investments in agricultural operations above 10,000 hectares (ha) in Africa. ${ }^{7}$

\footnotetext{
${ }^{5}$ For greater detail, please see Deborah Bräutigam and Tang Xiaoyang, "China's Engagement in African Agriculture: 'Down to the Countryside,'" China Quarterly 199:686-706.

${ }^{6}$ See Deborah Bräutigam, Chinese Aid and African Development: Exporting Green Revolution (New York: St. Martin's Press, 1998).

${ }^{7}$ This could always change. For commentary and links to research on this topic, see Deborah Bräutigam's blog at www.chinaafricarealstory.com and search on "land grabs."
} 


\section{Tanzanian Agricultural Strategy}

Fifty years after independence, Tanzanian agriculture remains dominated by smallholder farmers growing food crops with hand hoes, dependent on an uncertain rainfall. Yields are low. As a result of the marketoriented reforms, the entire agricultural sector - such as production and processing, input importation and distribution, and agricultural marketing - has opened up to private investment, and the private sector is now expected to carry out most of the production, processing, and marketing functions (Government of Tanzania n.d.). The Agricultural Sector Development Strategy, prepared in 2001, has set the road map for the sector until 2025. That strategy aims to improve market dynamism by strengthening the institutional framework, creating a favorable environment for commercial activities, clarifying public and private roles in providing services, and improving market efficiency (Tanzania, Ministry of Agriculture 2001, 8-9).

Correspondingly, the Kilimo Kwanza program, which was initiated in 2009 to foster a Tanzanian green revolution, focuses on facilitating commercial financing, building public-private partnership, providing fiscal incentives, removing market barriers, and promoting investment in agriculture-related industries (Tanzania, Ministry of Agriculture 2009).

In this connection, agricultural research and extension services will be decentralized to local communities and be outsourced to nongovernmental organizations (NGOs) and private groups. Similarly, local communities and various stakeholders will be given the responsibility to manage small-scale irrigation schemes, develop local renewable energy programs, and construct local housing. The government will continue rehabilitating the road network, which is in poor condition (Tanzania, Office of the Prime Minister 2001). 


\section{CHINA AND TANZANIA HISTORICAL BACKGROUND, 1964-1999}

China's assistance to agriculture and rural development in Tanzania has been extensive, with multiple projects going back to the first economic and technical cooperation and loan agreements in 1964. Between 1964 and 1970, China financed the Ruvu State Farm, the Upenja State Farm, the Urafiki Cotton Textile Factory, the Ubongo Farm Implements Factory, the Mbarali Rice Farm, and at least four farmer training centers. The Tazara Railway was built between 1970 and 1976. In subsequent years, Chinese teams remained or returned to many of these projects, attempting to keep them afloat. However, few Chinese investors were interested in bidding on such assets when Tanzania began to privatize many of its state-owned companies.

\section{Ruvu State Farm}

In 1965, China and Tanganyika agreed to co-finance the Ruvu State Farm, a 2,834-hectare (ha) development located 50 miles west of Dar es Salaam. The farm itself developed 810 ha for rice, cotton, vegetables, and cereals (other reports put the total at 720 ha), while 2,834 ha were dedicated to fruit trees, dairy, and beef cattle, for a total cost estimated at between US $\$ 1.1$ and $\$ 1.4$ million. ${ }^{8}$ China agreed to meet the recurrent costs of the project until it was self-sustaining (Ogunsanwo 1974, 140). In addition, the Chinese financed a $\$ 14$ million irrigation and hydroelectric dam on the Ruvu River to provide power for the farm(Yu 1970, 54-55). The Ruvu State Farm was set to be privatized in the late 1990s, along with other state farms (Indian Ocean Newsletter 2000). ${ }^{9}$ As of January 2009, however, the Ruvu Farm hosted small-scale farmers and comprised 1,215 ha (Land Rights Research and Resources Institute 2009).

\section{Upenja State Farm}

The island of Zanzibar received finance and Chinese assistance for the Upenja State Farm (526 ha) between 1965 and 1969. Upenja was designed to be a modern, mechanized farm with rice, beans, tropical fruits, poultry, and vegetables. The Chinese trained Zanzibaris in harvest operations, tractor driving, and machine repair (Ogunsanwo 1974, 203). Irrigation was done via 13 deep wells. The project appears to have been somewhat controversial in Zanzibar. In recollecting the project today, a Zanzabari told us that "all mango trees which helped to bring rain were bulldozed despite popular acclaim against it" (Pers. comm. 2011). ${ }^{10}$ Another Zanzibari told us that Upenja "never reached the goals" set out at the beginning, although it is "still operating as a state farm under the Ministry of Agriculture and Natural Resources" (Pers. comm. 2011). ${ }^{11}$ He noted that the Chinese have expressed interest in supporting agricultural projects in Zanzibar and were interested in "trying to revive the old projects that were assisted by them in 1960s." So far, the Upenja Farm has not been on this list, however.

\section{Maziwa-Ngombe and Wete Road}

In 1964, on the small island of Pemba north of Zanzibar, a Chinese team built a road between MaziwaNgombe and Wete, a distance of approximately 20 miles (Bartke 1975, 183). This appears to be the only road project ever financed out of Chinese aid in Tanzania.

\footnotetext{
${ }^{8}$ All dollars are U.S. dollars.

${ }^{9}$ A 2000 report in the Indian Ocean Newsletter mentioned Chinese interest in farm management and in agribusiness processing cashew nuts and fruit juice in Ruvu and Mbarali (discussed later), but we found no trace of this interest in our research.

${ }^{10}$ Personal confidential email communication, October 23, 2011.

${ }^{11}$ Personal email communication from member of House of Representatives, Zanzibar parliament, October 24, 2011.
} 


\section{Tanzania-Zambia (Tazara) Railway}

China's largest aid project in Africa to date remains the iconic Tanzania-Zambia (Tazara) Railway1,860 kilometers long, running from the port of Dar es Salaam to join an existing line at New Kapiri Mposhi in Zambia. Discussions on the project began in 1964, with feasibility studies and subsequent agreements signed in 1967, and the final agreement being signed in 1970, the same year that the work began. Built between 1970 and 1976, this project was financed by a zero-interest loan of almost 500 million Renminbi yuan (RMB) (\$286 million) and a grant of \$28.6 million. It also included construction of a center that could train 200 people at a time (Ai 1999). The purpose of the railway line was to open up rural areas of Tanzania and Zambia, and to enable Zambia's copper to reach the sea without being held hostage to South Africa, controlled at that time by a hostile regime. The railway is still supported by the Chinese government, which provides regular, concessional loan-based financing.

\section{Mahonda State Sugar Cane Farm and Processing Factory}

In Zanzibar, China began building the Mahonda State Sugar Cane Farm and Processing Factory in 1974, about 25 kilometers north of Zanzibar town. The feasibility study for the project was done in 1970 Bartke $1975,189)$. The factory processed cane grown on a 1,216 ha plantation, which also seems to have been developed with Chinese assistance. In the mid-1980s, Chinese experts returned to revamp the factory, financed by a 20 million Tanzanian shilling (TSH) soft loan; they did not stay, however. In 1996, China offered Zanzibar \$2 million for additional rehabilitation of Mahonda, among other projects(Xinhua 1996). ${ }^{12}$ However, the factory was plagued by problems of embezzlement and mismanagement under Zanzibari management. Production at the adjacent plantation had declined from an annual 6,000 tons to 500 tons, workers suffered significant salary arrears, and when the factory closed in 1998, they were suspended without having been paid (Indian Ocean Newsletter 1998). Although Mahonda was offered under the privatization program, and sparked some interest among Indian, Spanish, and Chinese investors, it was ultimately shut down and remained closed until 2004, when it was purchased by a local Indian private investor, who is apparently also struggling to run it profitably (Matango 2006, 5).

\section{Mbarali Rice Farm}

China's most extensive agricultural aid project in Tanzania was the Mbarali Rice Farm in Mbaye, built between 1971 and 1977 and managed with Chinese technical assistance for several decades thereafter. The Mbarali District lies in the southern Usangu plain, "famously known as the 'national rice basket' because it used to yield up to 60 percent of the rice consumed in Tanzania." (Land Rights Research and Resources Institute 2009, 64) Mbarali had its origins in 1958 when the Tanganyika Agricultural Corporation developed irrigated rice with the assistance of the FAO. The Chinese government signed an agreement to develop a rice station at Mbarali in 1964. The task was assigned to the Department of Agriculture and Forestry of Jiangsu Province. Construction began in 1971 and finished in September 1977. The cost came to RMB 24.9 million (\$13.4 million) (Ai 1999).

According to one source, the Chinese team developed 3,530 ha, half of which was new and half reclaimed Xue 2010). The Land Rights Research and Resources Institute (LRRRI) put the size at 5,575 ha in 1977 and 5,842 ha in 2009 (LRRRI 2009). Mbarali was a self-contained state farm, with its own irrigation and drainage, barrages to control floods, 320-kw hydropower system, piggery, dairy farm with 100 cows, poultry farm with 50,000 chickens, rice mill with an annual capacity of 8,000 to 10,000 tons, and staff housing. The Chinese developed it as a highly mechanized system, employing 393 full-time workers and 73 on contract. According to Chinese sources, when Mbarali was at full production, it supplied 25 percent of Tanzanian market demand, and it was able to repay the initial investment within six years (Xue 2010,2). Yields during that period were as high as 8 tons (Figure 2.1). ${ }^{13}$ According to a

\footnotetext{
It's not clear whether this was taken up.

${ }^{13}$ This story of Mbarali is mainly drawn from Ping, "From Proletarian Internationalism," pages 177, 180, and 198.
} 
Chinese source, "The shining example of the farm had also promoted rice production in the surrounding area. Small farmers in the area grew more than 2000 ha of paddy rice with annual output of more than 6,000 tons."

Figure 2.1-Mbarali rice farm yield (tons/ha)

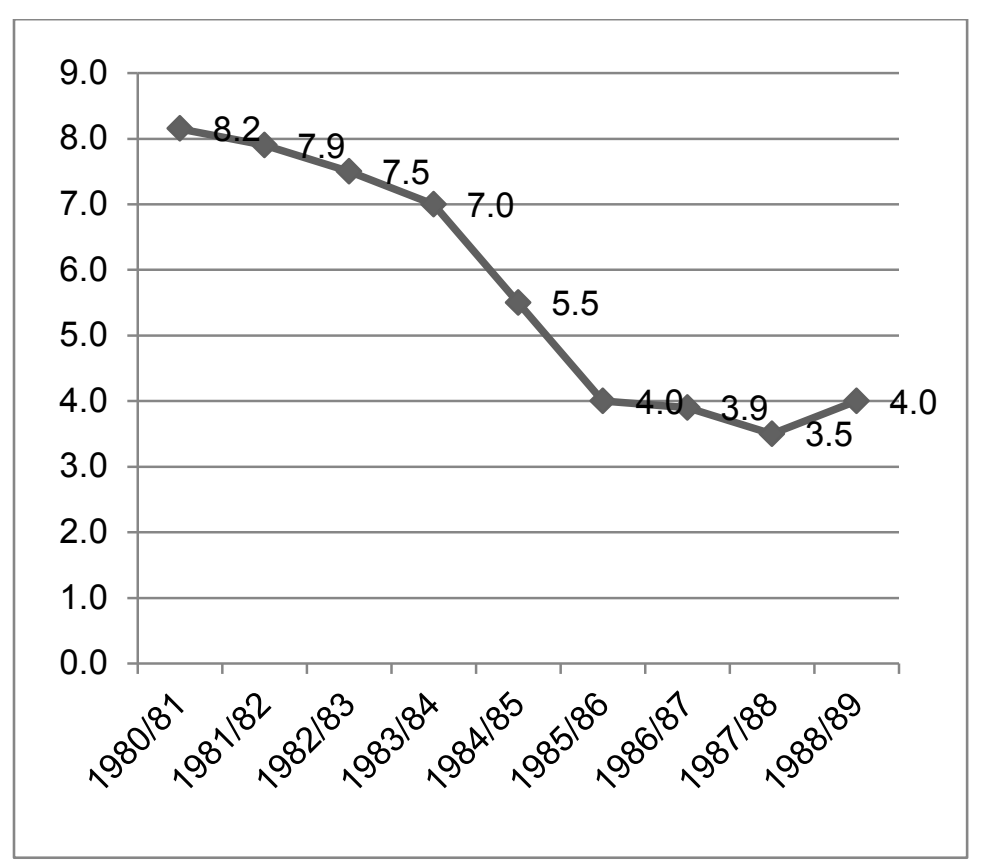

Source: Adapted from Duwayri, Tran, and Nguyen(1999).

The farm was formally handed over in 1977, but teams of Chinese experts were attached to it in rotating teams, each team providing assistance for two years. Ten teams served, until July 1999 (the eighth team stayed for four years). The farm finally closed in 2001. Each of the first eight teams consisted of 20 experts, but the number of team members was reduced to 13 in the last two runs (Pers. comm. 2011). ${ }^{14}$

The Chinese government provided loans to pay for spare parts and new farm machinery. After the farm was handed over, however, production declined sharply, from an average of 8.2 tons/hectare to less than 4.0 tons (Figure 2.1). The Chinese explain this as being due to economic hardship and foreign exchange shortages, which made it difficult to procure spare parts, keep machinery repaired, and provide fertilizer and pesticides. At these lower yields, when Tanzania liberalized rice marketing, Mbarali could no longer compete with small farmers.

As Tanzania began to offer some state assets for privatization in the mid-1990s, the Jiangsu Province team investigated the possibility of transforming Mbarali into a commercial joint venture. Yet the Tanzanian government at that point required Tanzanians to have a majority share. Jiangsu did not believe Mbarali could be made to operate profitably unless they controlled the management. Believing in "noninterference," they did not press the issue.

The privatization of Mbarali was "a dramatic process" that began in 2001 and "stalled for a long time" (LARRI 2009, 68-69). In the 2003-2004 budget speech, the former minister of agriculture announced that Mbarali and Ruvu would be privatized to smallholders. A number of smallholders were leasing or otherwise using land to grow rice around Mbarali. However, in 2004-2005, the government changed course and announced that Mbarali would be put up for sale. The farm was purchased by

\footnotetext{
${ }^{14}$ Chinese Academy of International Trade and Economic Cooperation, Beijing, email communications, December 5, 2011, and December 6, 2011.
} 
Highland Estates Limited, a company owned by Nawab Mulla, a local investor and CCM Chama cha Mapinduzi (The Ruling Party in Tanzania) politician whose family had built an irrigation canal in the region in the 1930s. The cost apparently was TSH 3.5 billion ( $\$ 2.2$ million), and the investor put in another TSH 2.72 billion ( $\$ 1.7$ million) to renovate and upgrade equipment. He has subleased 2,500 ha to cooperative groups of 884 smallholders and provided water. But some complain that leases require a minimum acreage that is prohibitive for some smallholders.

\section{Agricultural Extension and Farmer Training Stations}

In addition to the large state farms built in the early years of Chinese aid, the Chinese government also built at least five agricultural extension and farmer training stations. (Yu 1975) ${ }^{15}$ These stations seem to have been built in several rounds and were located in Morogoro, Dodoma, Mbeya, and Kagera regions, among others. Three agrotechnical popularization centers or stations were built in the late 1960s, at least one was built in the 1970s (Mbeya), and two were built in the early 1980s and handed over in a ceremony on December 23, 1983. ${ }^{16}$ The Mbeya Farmer Training Center included station buildings, housing, and a seven-hectare demonstration field (Ai 1999). ${ }^{17}$ The Mbeya Farmer Training Center was operated by the Agricultural Department of the Shanxi Provincial Government and was built by a team that had come to assist in the maintenance of the Tazara Railway. The purpose of Mbeya was to promote improved cultivation practices for maize and vegetables, including ox plowing, intensive cultivation, and timely harvesting. In 1996, the Mbeya station was still active (Ai 1999). All the stations were of relatively modest size. According to one researcher, construction costs for the first three stations built in the late 1960s were estimated to total $\$ 64,000$; the Mbeya Farmer Training Center built in the late 1970s was estimated to have cost $\$ 14,000$ (Yu 1975, 84). However, a researcher with access to internal Chinese documents reported that the Mbeya station cost RMB 920,000 ( $\$ 486,000$ at the exchange rate used then). Officials we interviewed at the Ministry of Agriculture in Tanzania were not familiar with any of these stations, and there does not seem to be much of an institutional memory of this contribution.

\section{Urafiki Textile Factory}

The Chinese also built several factories in addition to the Mahonda sugar mill that may have had an impact on agriculture and rural development in Tanzania. The Urafiki (or "Friendship") Textile Factory was opened July 6, 1968, on the outskirts of Dar es Salaam. Although the Chinese had proposed a more automated technology, the Tanzanians insisted on a very labor-intensive design (Yu 1975, 82). The cost of Urafiki was estimated to be, at the time, between $£ 2.5$ million and $£ 3.32$ million (Bartke 1975, 184). At full operation, Urafiki consumed 30,000 bales of cotton annually, about a tenth of Tanzanian production, and had more than 2,000 workers. It was privatized in 1997 and purchased by a Chinese provincial company that now owns 51 percent, with the Tanzanian government maintaining a 49 percent share. The Chinese government has bailed the factory out on several occasions with soft loans (Pers. comm. 2008). ${ }^{18}$ Early in 2011 the factory was closed for several months when it had trouble obtaining enough raw cotton.

\section{Ubongo Farm Implements Factory}

The Ubongo Farm Implements Factory was constructed by the Chinese between 1968 and 1970 in the Ubongo suburb of Dar es Salaam, at a cost of around $\$ 756,000$ (it was said to be valued at $\$ 1.3$ million in 1971) (Yu 1975, 79). After opening in 1970, the factory operated with 140 workers but had difficulty

\footnotetext{
${ }^{15}$ George Yu reports that the Chinese built four farmer training centers between 1967 and 1968: Kilosa (which is in Morogoro Region), Budoba (this may be Bukoba, in Kagera Region in the north of the country), Mbulu (Manyara Region), and Mbeya (Mbeya Region). p. 84. It is not clear which exchange rate was used.

${ }_{16}$ Local Chronicles of Anhui Province (Book XVII, Chapter 2, section 5, §3), mentions a "Bihawana" promotion center. It is not clear if these were the same stations that were constructed in the late $1960 \mathrm{~s}$.

17 All of the information on the Mbeya station comes from this source.

${ }^{18}$ Chinese official, interview, January 2008, Dar es Salaam.
} 
operating at capacity because of foreign exchange and raw material shortages. Nevertheless, the factory was expanded in 1980 and, at its peak, was meeting some 85 percent of Tanzanian demand for hoes and other hand-operated farm tools (Ai 1999). Ubongo struggled to operate profitably and was ultimately privatized in the late 1990s or early in the 2000s and was purchased by a Chinese company. The company applied for financing from the China Eximbank but was turned down, and the factory was again shuttered (Pers. comm. 2008). ${ }^{19}$ China also had a farm implement factory in Zanzibar.

\section{Food Aid}

China supplied food aid to Tanzania at least twice during this period (1985: \$1 million; 1999: amount unknown) (Bräutigam 2011a).

\footnotetext{
${ }^{19}$ Chinese official, interview, January 2008, Dar es Salaam.
} 


\section{CHINA'S OFFICIAL AGRICULTURE AND RURAL AID PROJECTS, 1999-2011}

China has financed two agricultural aid projects in this recent period: a new agrotechnology research and demonstration center (2009-present) at Dakawa, Morogoro Region, and a small technical assistance project (2009-2010). In addition, a number of Tanzanians have been sent to China for university education and for short training courses, many of which focus on agriculture. A rural water project continues in its second phase, and the Chinese are completing construction of three rural schools and a fiber-optic cable system that is linking towns and cities in Tanzania for speedy broadband connectivity. China also contributed food aid and made some agriculture-related donations.

\section{Agrotechnology Research and Demonstration Center (2009-present)}

Built at Cholima, Dakawa, Mvomero District, Morogoro Region, the Sino-Tanzania agrotechnology research and demonstration center was designed and constructed by a state-owned company, the Chongqing Zhongyi Seed Company, as part of the Chinese pledge in November 2006 to build 10 (increased in 2009 to 20) agrotechnology demonstration centers in Africa as part of FOCAC. These centers are designed as an experiment. The Chinese government will finance the construction and support a Chinese team to continue to manage or provide assistance at the center for an additional three years. In the original plan, the Chinese company was supposed to use this opportunity to develop commercial activities that might enable the center to be self-sustaining (Bräutigam 2011b, 248-252).

Knowing that the model involved an experimental public-private partnership and that teams would bid in a public tender held in China, a team from a state-owned agribusiness company and research institute in Chongqing visited Tanzania in 2008 to investigate opportunities. ${ }^{20}$ In a May 2008 interview with the Chongqing Evening News, the company said that it had selected an area of 300 ha in Tanzania and planned to establish an outgrower operation using its patented hybrid seeds, which would be provided to local farmers (China Daily 2008 and Zou 2008). It envisioned exporting some of the grain back to China.

The Chongqing research center and its agribusiness made an effort to be selected for the Tanzania project. Chongqing Zhongi formed the Chongqing Sino-Tanzania Agriculture Development Company. The Tanzanian government provided four potential sites for Chongqing to choose from. Three of the spots were too remote or too challenging, and the Dakawa site, while close to an existing Tanzanian agricultural center, also had a problem - lack of water. According to the agreement, the Tanzanian Ministry of Agriculture promised to build a pump and pipeline connecting the center to a small river three to five kilometers away, but this has not been done. The Tanzanian side is also supposed to pave the road to the center (not done yet) and bring electricity to the center (although this has been done, blackouts are frequent and the center has its own generator).

After the selection of the 62-hectare site in Morogoro, construction of the center lasted 13 months (October 2009 to November 2011), and the center was formally handed over April 2, 2011, in a ceremony attended by Tanzanian president Jakaya Kikwete. It comprises 10 ha of experimental fields (hybrid and conventional rice, maize, horticulture), two ha for an office, laboratory, and training complex, and 50 ha of outside fields equipped with irrigation and drainage channels. The center, which will focus on advanced seed technology, has a dual function: research and training. It includes a modern poultry and egg complex, a greenhouse, tissue culture rooms, and four deep wells that supply water to one to three ha of the experimental fields during the dry season. Construction of the center came to RMB 40 million (about $\$ 6$ million) and was financed by a grant (Pers. Comm. 2011 and IPP Media 2011). ${ }^{21}$

Initial trials at the experimental plots found that rice yields with Chinese hybrids were four times that of local varieties, but local maize and the Chinese maize were not far apart. The Chongqing company

\footnotetext{
20 The Chongqing Seed Company's website is found at www.cqseed.com/.

${ }^{21}$ Chinese agricultural scientist, Sino-Tanzania Agriculture Development Company, interview, Dakawa, Tanzania, September 21, 2011.
} 
official we interviewed was skeptical about the potential for exporting hybrid rice seed to Tanzania (the seeds are intellectual property, so they cannot be reproduced locally). Tanzania has complicated phytosanitary seed importation procedures. He had observed that Tanzanian peasants believe fertilizer and pesticides are too expensive to apply. Local representatives of the Ministry of Agriculture responsible for the demonstration center called it a "good job; they are preparing a good place for doing work. Some people get ideas from them, local farmers" (Pers. comm. 2011). ${ }^{22}$

According to several officials familiar with the project and the Chinese themselves, local people do not care for the taste of Chinese rice. "Rice is our second staple," a Ministry of Agriculture official told us. "People eat rice in the evenings in towns because they have some money to buy it. But rice production is low. The potential is good for producing more. Rice is also served on special occasions. The Chinese rice is not as tasty as ours. We want to balance the two characteristics. We want varieties that are high yielding, but also tasty and with a nice aroma" (Pers. comm. 2011). ${ }^{23}$

The original plan called for the Chinese government to support the Chinese technicians and the centers in Africa for three years after completion. What that will involve in Tanzania is currently under negotiation between the two sides. At the opening of the center, local farmers appeared to desire direct training: "As hundreds of local residents witnessed the handover ceremony, they also expressed their intention to be trained at the centre" (IPP Media 2011). Yet according to the Chinese embassy and Chongqing, the center would mainly be training higher-level agricultural officers and technicians selected by the Tanzanian government, as they would need to be educated to take advantage of the level of training on offer at the center (Pers. comm. 2010). ${ }^{24}$

The Chinese team in place has no specific plans for the center, for outreach to local farmers, or for a credit system to enable adoption, and it sees these activities as the role of the Tanzanian side. As the center has been turned over to the Tanzanians, the Chinese regard it as the property of the Tanzanians. The Chinese will carry out three years of "software" (training and so forth) and then will probably depart. During that time, Chongqing will also use the center as a "platform" to look for other opportunities in Tanzania (see under investment below).

\section{Technical Assistance and Capacity Building}

As part of the FOCAC pledges to send 100 agricultural experts to Africa, China sent three Chinese experts to the Tanzanian Ministry of Agriculture between 2009 and 2010 to provide technical assistance, build capacity, and help organize training for Tanzanians in China. Two focused on promotion of advanced techniques and nontraditional crops (for example, soybeans); one was an irrigation expert. They proposed practical steps for government assistance to smallholder farmers. One had served in Nigeria before and spoke English well, the others not so well, "but we could easily communicate" (Pers. comm. 2011). ${ }^{25}$

\section{Agriculture-Related Training Programs in China}

In connection with the 2006 FOCAC pledge to offer short-term training to up to 30,000 Africans, China has offered a number of agriculture-related training programs in China for Tanzanians. For example, China has provided intensive short-term training (usually three weeks) on agricultural management, handicraft production, and fishery techniques for Zanzibari officials and technicians every year since 2006. At first, 10 to 20 Zanzibaris were sent to China every year. Starting in 2009, the number has significantly increased. In 2009, it was 70, in 2010, more than 100, and in 2011, it nearly reached 200. Previously, the trainees joined training programs with a mix of people from around Africa, but now it appears that some at least will travel in their own program. In September 2011, for example, China

\footnotetext{
${ }^{22}$ Ministry of Agriculture representative, Dakawa regional agricultural center, interview, Morogoro, September 22, 2011.

${ }^{23}$ Deputy permanent secretary, Ministry of Agriculture, interview, Dar es Salaam, September 29, 2011.

${ }^{24}$ Economic officer, Chinese embassy, interview, Dar es Salaam, September 19, 2010.

${ }^{25}$ Policy and planning official, Ministry of Agriculture, interview, Dar es Salaam, September 26, 2011.
} 
offered an aquaculture training class for 30 Zanzibari fishermen and one official (Pers. comm. 2010). ${ }^{26}$ The trainees, said to be ordinary fishermen, were selected by the Zanzibari fishery ministry (probably with some limits like language and age). They spent a month in Xiamen visiting various kinds of aquafarming projects.

\section{Chalinze Rural Water Supply Project}

China has provided grant finance for and constructed two phases of the Chalinze Rural Water Supply Project (2001-2003; 2007-2015). The first phase of Chalinze began in 2001 and ended in 2003, and supplied piped drinking water to 20 villages - about 62,961 people (Pers. Comm. 2008; People's Daily 2001). ${ }^{27}$ The final phase should bring the total beneficiaries to more than 100,000 . As described by the Chinese: "China has completed a drinking water network in central Tanzania and is training local staff to operate it" (Xinhua 2009).

The Chalinze area is semiarid, the groundwater is not potable, and the water table falls during the dry season. The entire pipeline to the villages from the Chalinze water treatment center is $126 \mathrm{~km}$, and the distribution pipe $34 \mathrm{~km}$. Water delivered through this project has metered standpipes monitored by village members who collect money for each liter (USAID 2008). China Hainan International Cooperation carried out the project, with some 50 Chinese and about 500 local workers (Pers. comm. 2008). ${ }^{28}$ According to the Ministry of Water, the first phase of the project cost TSH 23 billion (approximately \$14.6 million) (Tanzania, Ministry of Water n.d.) On April 27 and May 11, 2007, the Chinese embassy signed two agreements to continue to support maintenance and expansion of the Chalinze Water Project. A survey team was dispatched in January 2008 to review the existing work and map out the extension of Chalinze. Construction was ongoing during our visit in September 2011.

\section{Three Rural Primary Schools}

The Chinese government is building at least three rural primary schools in Tanzania (Tanzania, Ministry of Commerce 2009). One was built between May 2009 and January 2011 by the Beijing Construction Engineering Group in President Kikwete's hometown of Msoga, about $110 \mathrm{~km}$ west of Dar es Salaam at a cost of RMB 5 million $(\$ 750,000)$. Another, Laalakiri, was built in Partimbo ward of Kiteto, an "international special talents school" but apparently focused on educating the pastoral community (Arusha Times 2010). A third is in a village on the west coast of the island of Zanzibar. Each school is intended to serve 300 students (Pers. comm. 2010). ${ }^{29}$

\section{National Fiber-Optic Backbone Project}

China has provided two concessional loans for Tanzania's national fiber-optic backbone project. The first phase of the $10,674 \mathrm{~km}, \$ 170$ million project was completed in May 2010 with concessional loan financing from the China Eximbank. The China Communication Construction Company (Tongxin Jianshe Jituan, a subsidiary of China Telecom) is carrying out the project. The first phase of 7,000 km connected Tanzania's major cities in the north and the east—Rwanda, Dar es Salaam to Tanga, Moshi, Arusha, Singida, Dodoma, Iringa, and Morogoro - and provides connections to Burundi, Kenya, and Uganda. The China Eximbank provided a new concessional loan of RMB 700 million ( $\$ 100$ million) for the second phase (Information Policy 2010). The second phase will link Dar es Salaam to Kigoma, Taborak, Sumbawanga, Mbeya, Songea, Mtwara, and Lindi as well as connect to Zambia and Malawi.

\footnotetext{
${ }^{26}$ Chinese consulate, interview, Zanzibar, September 26, 2010.

${ }^{27}$ Pascal Hamuli, project manager, Chalinze Water Project, interview, January 7, 2008.

${ }^{28}$ Interviews, Dar es Salaam, January 2008.

${ }^{29}$ Chinese official, interview, Dar es Salaam, January 8, 2008. There may be more than three rural schools being built under this program.
} 
The project is expected to bring broadband connectivity closer to rural villages and reduce connection costs by some 80 percent (Reuters 2010).

\section{Agricultural Machinery Donations}

China donated tractors to Tanzania in 2000. In 2005, China donated $\$ 123,615$ worth of agricultural machinery, including three heavy-duty tractors, seven power tillers, two milling machines, and two water-pumping systems (Xinhua 2005). 


\section{OTHER RECENT AGRICULTURAL/RURAL COOPERATION, 1999-2011}

Several other areas exist where Chinese engagement is relevant for agriculture and rural development. None is financed under China's aid budget. Cooperation between the CDB and the Bank of Tanzania is ongoing with regard to the proposed establishment of the Tanzania Agricultural Development Bank. The United Nations Industrial Development Organization (UNIDO) helped coordinate and finance the purchase of Chinese biogas technology and study tours to biogas sites in China in connection with a pilot project at the commercial Kitani Sisal Farm, which is locally owned. The World Bank has supported efforts by the International Poverty Reduction Center of China (IPRCC 2011a) to engage Tanzanian officials on the Chinese experience of policy reform in agriculture. ${ }^{30}$ The World Bank coastal area development project sent Tanzanian officials to China on a study tour of fisheries and coastal management. IPRCC commissioned a pre-feasibility study for a microfinance center in the town of Morogoro, in cooperation with a major local microfinance organization, PRIDE. IPRCC is also implementing a small community development project in the neighborhood of the sisal farm operated by a Chinese state-owned company. Although the Chinese government has not financed any roads in its aid program in Tanzania since the 1960s, several dozen Chinese companies compete for road construction projects financed by the government and donors.

\section{Tanzania Agriculture Development Bank (2009 to Present)}

Several years ago, the Tanzanian government requested Chinese assistance with its long-standing plan to establish an agriculture development bank. A month after President Hu Jintao's visit to Tanzania in February 2009, the CDB chairman, Chen Yuan, visited Tanzania and signed a framework cooperation agreement with the head of the Bank of Tanzania, Benno Ndulu, regarding future cooperation (IPP media 2009). The bank is seen as part of Tanzania's Kilimo Kwanza agricultural modernization program. The Centre for Chinese Studies (2010) noted that the CDB had agreed to provide technical and unspecified financial support and would begin by financing several feasibility studies, including a currency swap program and a program to provide local Chinese businesses with loans in Tanzanian shillings (Centre for Chinese Studies 2010). ${ }^{31}$ An Indian consultant carried out the pre-feasibility study for the agriculture development bank (Pers. comm. 2010). ${ }^{32}$ The local CDB working team reports that the research department at $\mathrm{CDB}$ headquarters is studying the pre-feasibility study for the agriculture development bank (Pers. comm. 2011). ${ }^{33}$ The program has not yet been implemented, although two and a half years have passed. The Chinese hesitation may stem from problems that others have identified with Tanzanian government banks: how to ensure that they avoid the portfolio risk of providing loans for government officials and politicians who do not intend to repay (Centre for Chinese Studies 2010).

\section{Peiyapeiya Village Community Development Project (2008 to Present)}

IPRCC has done research since 2008 in Tanzania, led by China Agricultural University professor Li Xiaoyun, who is affiliated with IPRCC. IPRCC commissioned a pre-feasibility study for a microfinance center in the town of Morogoro, in cooperation with a major local microfinance organization, PRIDE. The head of PRIDE is on the board of IPRCC. Samuel Wangwe, a Tanzanian economist who is on the board

\footnotetext{
${ }^{30}$ According to an IPRCC press release (2011a), "Peiyapeiya Village is affiliated to Ludaiwa, Kidmanba Town of Kilosa County. It is one of the six villages in Ludaiwa, with four natural villages, having population of 2481 and covering an area of some 4000 ha. There are 454 peasant households and 581 labors in the village. The villagers are mainly engaged in crop farming including corn, paddy and sunflower."

${ }^{31}$, Evaluating China's FOCAC Commitments to Africa and Mapping the Way Ahead, report prepared for the Rockefeller Foundation, January 2010, p. 112.

${ }^{32}$ Deputy permanent secretary, Ministry of Agriculture, interview, Dar es Salaam, September 29, 2011.

${ }^{33}$ China Development Bank official, telephone interview, Dar es Salaam, Tanzania, September 29, 2011.
} 
of IFPRI, carried out the pre-feasibility study. Apparently IPRCC decided against moving forward with the microfinance center (Pers. comm. 2011). ${ }^{34}$

Meanwhile, a local Chinese-owned sisal farm had done several community projects (repairing local schools, sponsoring local soccer teams) but was interested in doing more. The managing director went to Beijing during a home leave and asked Chinese NGOs for advice. He eventually got in touch with IPRCC and China Agricultural University. This cooperation is the result (Pers. comm. 2011). ${ }^{35}$ In January 2011, a research group from IPRCC spent six days conducting field research in Peiyapeiya Village, Morogoro Province. Peiyapeiya Village, with about 2,400 residents, is one of six villages in the vicinity of the sisal farm (IPRCC 2011a). The sisal farm is the major employer of people in the village (the area offers no other real opportunities for paid employment). IPRCC proposed to the local villagers' committee that they cooperate in a pilot community development demonstration project for the village, together with the sisal farm (IPRCC 2011b).

The community together with researchers from IPRCC and the farm managers decided on a plan for this cooperation. The first step involved rebuilding the village community center, replacing a 20square-meter building with one that is $200 \mathrm{~m}^{2}$. The design is by a local engineer, and the work is being carried out entirely by community members, with funds provided by IPRCC. Construction began April 24,2011 . When the center is complete, cooperation will turn to small-scale training with activities decided by the community. The sisal farm serves as the local liaison for the project and has pledged to bring in appropriate trainers. IPRCC will provide funds for training activities, and the farm is prepared to assist with fuel, seed, and other materials. A revolving loan program is also under discussion.

\section{World Bank South-South Knowledge Exchange: China-Tanzania (2008 to Present)}

The World Bank (2011) has cooperated with IPRCC to finance bringing senior Tanzanian officials to China for exposure to China's agricultural reform experience. Professor Li Xiaoyun is also involved in this effort. For the last two years, the World Bank has operated a trilateral cooperation project with IPRCC on policy reform for agriculture, to foster a learning process on agricultural reform. This project had its origins in December 2008, when IPRCC hosted a "Workshop on Development and Poverty Reduction in China and Africa." In 2009, IPRCC sent Professor Li Xiaoyun and several others on a visit to Tanzania. They met with the World Bank country director, who proposed some kind of cooperation, and remained very supportive of this effort. Professor Li was commissioned to write two papers - one on agricultural policy and one on smallholder-based agro-industrial clusters.

Both the World Bank and IPRCC were enthusiastic about this cooperation, which involved at least one delegation to China between November 22, 2010, and December 3, 2011 (Pers, comm. 2011). ${ }^{36}$ According to the World Bank (2011, 1), "the knowledge exchange raised the awareness of Tanzanian policymakers and changed some delegates' beliefs about the importance of entrepreneurship in the agricultural sector and the role of the state in promoting private sector-led growth." With the departure of the World Bank officials in China and in Tanzania who were involved in the cooperation, the effort has slowed. However, in connection with this knowledge exchange effort, a Chinese team was scheduled to visit Tanzania in 2011 to do a feasibility study for Tanzania's Maize Green Basket cluster (World Bank 2011).

\footnotetext{
${ }^{34}$ Professor Li Xiaoyun, personal email communication, September 23, 2011.

${ }^{35}$ Managing director, sisal farm, interview, September 20, 2011.

${ }^{36}$ World Bank economist, interview, Dar es Salaam, September 27, 2011. The permanent secretary in the prime minister's office, Peniel Lymio, was the key counterpart on the Tanzanian side. The cost of the mission was $\$ 131,000$.
} 


\section{UNIDO Tanzania-China Biogas Study Tours (2009 to Present)}

UNIDO is involved in an effort to provide technical expertise and build capacity in the sisal sector (Pers. comm. 2011). ${ }^{37}$ One of its projects is to promote biogas production on Tanzanian sisal farms. It selected a progressive sisal farm, Kitani, as its partner. A German company was contracted to work on the biogas, and it subcontracted to a Chinese firm with experience. A $150 \mathrm{kw}$ trial project was launched and expanded later to $300 \mathrm{kw}$. The Chinese involvement began simply as a supplier, but Kitani requested more involvement - for example, organizing study tours to China to see how biogas is used in rural areas. A round of visits ensued. UNIDO has provided some modest funding to support this learning effort.

\section{Agricultural Donations}

A number of Chinese companies and organizations have even more modest community and social development projects in rural areas. In Zanzibar, for example, the Chinese women's association in Beijing has donated several tractors, agricultural tools, and office equipment valued at several hundred thousand RMB to the ZAYEDESA (2009) center for youth education, employment, and development. The ZAYEDESA center was founded by the wife of a previous president of Zanzibar. Five or six years ago, the Chinese consulate in Zanzibar donated a poultry incubator to the center (Pers. comm. 2011). ${ }^{38}$

\section{Road Construction}

The Chinese government has not financed any roads or bridges in Tanzania in this period, but Chinese companies have won tenders for infrastructure projects of this kind and have constructed at least 30 roads in the country (Pers. comm. 2011) ${ }^{39}$ In 1991, the Sichuan Corporation for International Technical and Economic Cooperation competed with 10 other companies to win a World Bank-financed road construction tender for a $230 \mathrm{~km}$ road in Tanzania. Chinese companies have been building roads in Tanzania ever since. The World Bank estimated in 2008 that Chinese companies won about half of the road contracts (Pers. comm. 2008). "We can do a $100 \mathrm{~km}$ road for $\$ 30$ to $\$ 40$ million, while others can only do it for $\$ 50$ million," the Chinese economic counselor said (Pers. comm. 2008). ${ }^{41}$ Many Europeans raised issues of quality: "The Chinese will be a permanent headache. Now there is a tender, the Chinese might win, but will it be good quality?" asked a World Bank official (Pers. comm. 2008). ${ }^{42}$ A European ambassador said, "I'm not too concerned about the competition - they will come back to us - they'll see the difference. A Chinese road will have 3-cm tarmac, and a European road will have 12 to $15 \mathrm{~cm}$." (Pers. comm. 2008) ${ }^{43}$

Tanzanians were more positive about the quality: "They leave a lot of good work," said an official in the Ministry of Labour, Youth, Employment, and Development (Pers. comm. 2008). ${ }^{44}$ A senior official at the Ministry of Planning said, "Chinese construction companies are cheaper. Very good technical expertise. But there are some cases-Zanzibar Airport, a road-where there were problems. In those cases we got rid of them. Where they are not doing well, we won't use them. But I think the Chinese roads last. We have some Italian, Danish companies that have done terrible jobs." (Pers. comm. $2008)^{45}$

In 2008, an official Tanzanian government document stated that the government was concerned about delays in road construction by Chinese companies, and that "a number of companies spelled out to finish their tasks in time and sometimes end up with poor quality of the work." (Tanzania, Ministry of

\footnotetext{
${ }^{37}$ United Nations Industrial Development Organization, interview, Dar es Salaam, September 29, 2011.

${ }^{38}$ Chinese official, interview, Zanzibar, September 26, 2011.

${ }^{39}$ Chinese economic counselor, interview, Dar es Salaam, September 19, 2011.

${ }^{40}$ World Bank official, interview, Dar es Salaam, January 8, 2008.

${ }^{41}$ Chinese economic counselor, interview, Dar es Salaam, January 8, 2008.

${ }^{42}$ World Bank official, interview, Dar es Salaam, January 8, 2008.

${ }^{43}$ European ambassador, interview, Dar es Salaam, January 10, 2008.

${ }^{44}$ Official, Ministry of Labour, Youth, Employment, and Development, interview, Dar es Salaam, January 8, 2008.

${ }^{45}$ Official, Ministry of Planning, interview, Dar es Salaam, January 11, 2008.
} 
Foreign Affairs, 2). The Chinese embassy estimated that Chinese companies have constructed more than 30 road projects, but that all have been financed by others - the World Bank, the African Development Bank, and the Tanzanian government. He suggested that the problems tend to come in projects done for the Tanzanian government, many of which face significant construction delays because the contract requires payment after certain milestones, but this does not always happen, and sometimes roads are left in an unfinished state for too long (Pers. comm. 2011). ${ }^{46}$

\section{Port of Dar es Salaam Container Berths 13 and 14 (under Discussion)}

A feasibility study for a joint venture to build a ship repair yard at the Port of Dar es Salaam was undertaken in 1983, but apparently it did not go forward (Xinhua 1983). The Tanzania Ports Authority reported in June 2011 that it was in discussions with the Chinese government in the hope that it would finance the $\$ 523$ million cost of constructing two new container berths (numbers 13 and 14). A Chinese company, Jiaotong Jituan, has been in discussion with the Ports Authority about the project. "This is the idea of the Chinese companies," said the Chinese economic counselor (Pers. comm. 2011). ${ }^{47}$ The Tanzanian government and the company are still seeking finance for the port expansion. Apparently the Chinese banks are not convinced the project will be profitable enough to enable it to repay a loan. Furthermore, all loans to Tanzania must be concessional, with a 30 percent grant element and an interest rate of 2 percent or less, because of its HIPC (heavily indebted poor country) status. As concessional loans from China are limited, this project may not be financed, given that China has already financed the fiber-optic project and Terminal II at the airport with concessional loans. In countries like Tanzania with poor credit histories, Chinese banks will require some guarantee that their loans will be repaid.

\section{Yiwu Logistics Center (under Discussion)}

MOFCOM selected a company owned by the Chinese city of Yiwu to construct a major logistics center in Africa, carrying out a Chinese pledge made at the 2009 FOCAC (Pers. comm. 2011). ${ }^{48}$ The Yiwu company was asked to make its own decision about the site. It is interested in Dar es Salaam because of its location as a gateway to several other landlocked countries, and because it has the largest port in East Africa as well as a lively regional market (Kariakoo). The proposal is not final, and outstanding issues include land availability, location, and resettlement. The project would need to be close to the port, but also connect with the Tanzam railway and the airport. The Tanzania Investment Centre is "very much involved in this" as it allocates land for projects like this.

\footnotetext{
${ }^{46}$ Chinese official, Economic Office, Chinese embassy, interview, Dar es Salaam, September 19, 2011.

${ }^{47}$ Chinese official, interview, Dar es Salaam, September 19, 2011.

${ }^{48}$ Chinese economic counselor, interview, Dar es Salaam, September 19, 2011. Ministry of Foreign Affairs and International Cooperation, Asia Desk, interview, Dar es Salaam, September 29, 2011.
} 


\section{CHINESE FOREIGN DIRECT INVESTMENT IN AGRICULTURE AND RURAL DEVELOPMENT, 1999-2011}

Tanzania has requested that Chinese companies consider investing in water harvesting/storage and irrigation; agroprocessing; revival of dormant cashew-nut-processing and cotton-ginning factories and building new ones; and manufacture of farm implements including small tractors and power tillers (Tanzania, Ministry of Foreign Affairs and Ministry of FEA 2008). Although many Chinese companies have explored investment in agriculture in Tanzania, few have made the plunge. In 2011, the Chinese economic counselor commented that the Tanzanian side welcomed investment in agriculture (Pers. comm. 2011). ${ }^{49}$ Yet "agriculture is risky here," the former Chinese economic counselor said in 2008. "It is hard to have win-win" (Pers. comm. 2011). ${ }^{50}$ The largest Chinese investment in agriculture to date remains the China Agricultural Development Company's sisal farm.

\section{China State Farm Agricultural Company of Tanzania Sisal Farm (1999 to Present)}

Tanzania has a comparative advantage in the production of sisal fiber. African sisal output used to be 60 percent of the world total but by the late 1990s had dropped to 20 percent. In 1999, a state-owned enterprise, the China State Farm Agribusiness Corporation (since acquired by the China National Agricultural Development Company) invested in two abandoned sisal farms, Rudewa Estate and Kisangata Estate, established during the colonial period, nationalized, and later privatized by the Tanzanian government. The total area leased by the Chinese firm was 6,900 ha. It set up a company to run the two nearly contiguous farms: the China State Farm Agribusiness Corporation (Tanzania) Ltd. Ownership of the two sisal farms was recently transferred to a new company set up by the China Agricultural Development Company and the China Africa Development Fund.

The project was launched on December 24,1999 . The Chinese company applied for a $\$ 9$ million preferential loan from the China Eximbank but was granted only \$2.4 million, as the bank apparently was not convinced of the project's profitability. The total initial investment came to $\$ 3.5$ million. The site had not been used for some time, and almost no one was living on the farm. The company renovated the buildings and machinery and spent several years replanting sisal: 96 ha in 2000, 236 ha in 2001, 337 ha in 2002, and so on. Tanzania gave preferential policies, including a reduction in its annual land rent from TSH 600 to TSH 200 (less than RMB 2) per hectare.

Today the plantation is working 1,200 ha. There are four or five Chinese managers at the farm, several Chinese sales managers in Dar es Salaam, and up to 1,000 local workers. When the Chinese company bought the two nearly contiguous sisal farms in 1999, it invested around $\$ 1$ million of its own money. The sisal project was expanded again in 2007, at a cost of about $\$ 2.2$ million (Tanzania Investment Centre 2007). ${ }^{51}$ To date, the farm has invested $\$ 6.45$ million.

The sisal farm is the second largest in Tanzania. Two or three hundred workers live on site in free housing, with their families. A clinic is also provided. When we visited, only two Chinese managers were on site. The total of eight Chinese currently employed by the company in Tanzania, is "not enough," according to the managing director (Pers. comm. 2011). ${ }^{52}$ In most years, according to management, the farm breaks even, but in some years it suffers a loss. The farm is applying for funding from the $\$ 1$ billion clean energy project set up under FOCAC to construct a biogas digester to generate electricity. Half of its product is exported - some to China, some to the Middle East. Half is sold in Tanzania for local processing. Although the Chinese sisal farm is not considered particularly progressive, we found no

\footnotetext{
${ }^{49}$ Chinese economic counselor, interview, Dar es Salaam, September 19, 2011.

${ }^{50}$ Chinese official, interview, Dar es Salaam, January 8, 2008.

${ }^{51}$ The China State Farm Agribusiness Corporation was listed as owning 65 percent, with Jia Qing Quan as owning 35 percent.

${ }^{52}$ Unless otherwise noted, information on the sisal farm comes from our site visit and interviews with the managing director, Guan Shanyuan, Kilosa, Morogoro, September 22, 2011.
} 
complaints about its management or labor relations. ${ }^{53}$ A Tanzanian working with a more progressive sisal farm, Kitani, mentioned that the Chinese sisal farm was a member of the Tanzanian association of sisal farms:

They have not been very collaborative with local investors but [they] have made some significant investment especially in sisal farming. Therefore as investors in sensitive areas such as large scale agriculture ... there is a lot more that can be done to include the indigenous investors. ... Giving an example of the smallholder contracting scheme we [Kitani] are doing this has allowed the inclusion of local farmers in addressing both civil and economic issues. I believe this approach can benefit the Chinese investors (Pers. comm. 2011)..$^{54}$

\section{Urafiki (Friendship) Textile Factory (Late 1990s to Present)}

As noted earlier, Urafiki, a former Chinese aid project, was privatized in the late 1990s as part of a debtequity swap and bought by a Chinese company. Urafiki processes Tanzanian cotton and sometimes has difficulty securing enough supplies from local farmers, but it does not grow cotton.

\section{Boleyn International (2007 to Present)}

Boleyn International, a private Chinese firm, has launched several agricultural projects and an organic honey project using smallholder farmers. Boleyn is listed by the Tanzania Investment Centre as originally proposing to establish a rubber plantation. Its 81 ha farm in Tanga was launched in 2007. After experimenting with rainfed maize for the local market, but finding it could grow it only at a loss, it decided to invest in olive trees (for oil) and eucalyptus (a fast-growing tree that is used for telephone poles) (Pers. comm. 2011). ${ }^{55}$ The olives will take five to six years to mature, while the telephone pole trees will be mature in six to seven years. Boleyn recently won permission to develop another 243 ha of land to expand the olive grove. The permission was difficult to get, as the farm negotiates and buys land rights directly from local peasants. It plans to lease another 405 ha to grow castor oil. Boleyn is investing around $\$ 400,000$ per year and has no income yet from its agricultural projects. It plans to sell the trees locally and process the olives for export. The Tanga farm site has a 5,000-square-meter warehouse. The farm now employs scores of local workers and more than a hundred in the busy season.

\section{Honey King's Organic Honey Outgrower Scheme (2011 to Present)}

Boleyn International's forest beekeeping and organic honey processing project under subsidiary company Honey King Ltd. was scheduled for launch October 18, 2011, in Tabora, Tanzania (Pers. comm. 2011). ${ }^{56}$ Boleyn had earlier invested in Ethiopia but left because of foreign exchange controls that did not allow profits to be remitted outside of the country. The Tanzania project is intended to be run as an outgrower scheme, with the honey processing factory located in Kibaha. Honey King will finance the modern hives provided to local farmers but will charge approximately $\$ 50$ per hive, with the beekeepers paying for the hives over time in honey, "without interest." It will also provide training for the local beekeepers, which it believes will increase production from $20 \mathrm{~kg}$ per box to 50 to $80 \mathrm{~kg} /$ box. When we visited, Boleyn International's chief executive officer was in Argentina attending an international seminar on honey. Honey King planned to send its staff to attend an October 26, 2011, training workshop for Tanzania honey companies organized by the European Union, to introduce Europe's food product import policy.

\footnotetext{
${ }^{53}$ We asked about the sisal farm in a number of interviews.

${ }^{54}$ Kitani Sisal Farm, personal email communication, October 5, 2011.

${ }^{55}$ Official, Boleyn International, interview, September 27, 2011; official, Boleyn International, telephone interview, September 29, 2011.

${ }^{56}$ This section relies on an interview with a Boleyn International official, Dar es Salaam, September 27, 2011, and a telephone interview with a Boleyn International official, Dar es Salaam, September 29, 2011.
} 
Boleyn International said it was also benefiting from research on Tanzania's honey industry published in a report written by Chinese researcher Cheng Lihong (she is also the Chinese ambassador's wife).

\section{Other Commercial Farms}

We learned of another Chinese businessman from Zhejiang Province who is said to have invested in a 405 ha maize farm near Lake Victoria (Mpanda) with a local Tanzanian partner. The farm is mainly managed by the Tanzanian partner, while the Chinese partner has supplied seeds. The investors have a 30-year lease on the farm and grow maize for the local market. The same investor is also said to be purchasing sesame, cashew, and tea for export to India, Vietnam, and China, and has already exported up to 500 containers (Pers. comm. 2011). ${ }^{57}$ This project does not appear on the Tanzania Investment Centre list of projects for which incentives have been granted, and thus is probably not significant enough to be benefiting from special investment incentives. The same thing is true of at least two small private Chinese horticulture farms near the airport, which are growing vegetables for Chinese restaurants in Dar es Salaam.

\section{Suzhou Guoxin Pesticide Factory (2005 to Present)}

A Chinese company, Suzhou Guoxin, has been manufacturing agricultural pesticides, bacteria sterilizers, and herbicides in Tanzania since 2005. It sources raw materials from China, combines them in the factory, and sells wholesale. Its original plan was to source more raw materials locally (possibly pyrethreum), but shortages and electricity problems precluded this. The investment is approximately $\$ 2$ million (Pers. comm. 2011)..$^{58}$

\section{Biofuel Farming (Potential)}

Several European and American firms have moved to make large biofuel investments in Tanzania. Dr. Juma Ngasongwa noted in 2007 that "China wants to invest in cassava, maize and sugarcane cultivation for the production of ethanol and bio-fuel" (Agence de Presse Africaine 2007). As noted earlier, several Chinese companies continue to discuss agriculture-related business, often in joint ventures. Among those still in progress is an effort to obtain a preferential export credit for machinery, sponsored by the China CAMC Corporation (2010) and the Tanzanian conglomerate Super Group, which hope to build a \$155 million sugar plantation and mill at Wami Valley (Bagamoyo) and Pangani rivers in the Coast Region (the project has been under negotiation since 2007). Super Group is a local Tanzanian company owned by a Lebanese-Tanzanian family. In this case, it is not clear whether the Chinese partner would have simply been supplying machinery or would be an equity investor. An agreement has been signed between Super Group and CAMC, but officials were reluctant to share its contents as negotiations are ongoing (Pers. comm. 2011). ${ }^{59}$ The goal of the project would be to use sugarcane to produce ethanol (energy) (Pers. comm. 2011). ${ }^{60}$

Dacheng Group of Jilin and Stone Resources of Beijing began to explore a cassava project (industrial starch and biofuels) in 2007. Although we heard from a Chinese businessman that the project has already leased land, it does not appear on the list of Chinese projects at the Tanzania Investment Centre, a necessary step to gain work permits and other incentives. A Chinese official stated that the project was still under discussion and that financing was a constraint (Pers. comm. 2011). ${ }^{61}$

\footnotetext{
${ }^{57}$ Local Chinese businessmen, interview, Dar es Salaam, September 28, 2011.

${ }^{58}$ Official from Suzhou Guoxin, telephone interview, September 30, 2011.

${ }^{59}$ Super Group, interview, Dar es Salaam, September 29, 2011.

${ }^{60}$ Deputy permanent secretary, Ministry of Agriculture, interview, Dar es Salaam, September 29, 2011.

${ }^{61}$ Chinese counselor's office, interview, Dar es Salaam, September 19, 2011; Chinese Business Council, interview, September 20, 2011.
} 


\section{Mixed Farming (Potential)}

As noted earlier, the Chongqing company that is implementing the agrotechnology demonstration center has also been exploring investment in Morogoro Region. An NGO official who works on agricultural issues told us that he believed that the Chinese investment has already happened in Morogoro, that people have been evicted from their land, and that a Chinese company will be growing rice to export out of Tanzania (Pers. comm. 2011). ${ }^{62}$ It is possible the NGO official was mixing up the earlier media stories along this line with the reality of the agrotechnical demonstration center. Yet an investment could possibly happen in the future. The company told the Chongqing Business Daily in April 2009 that it had developed a joint venture in Tanzania of 1,822 ha and planned to build an "agricultural park" on the first 405 ha, starting in July 2009, focusing on rice, corn, eggplant, tomato, cabbage, and so on. This would have been the pilot phase, while the company decided whether to lease on a larger scale (Chongqing Business Daily 2009). The company secured approval from the Tanzania Investment Centre for a mixed farming project valued at $\$ 8.06$ million, which would employ 245 people. ${ }^{63}$ However, Chongqing has not gone forward with that plan. According to a Chinese official familiar with the project, although "the company's idea is good," it apparently has decided Tanzania is not a very promising location for foreign investment (Pers. comm. 2011). ${ }^{64}$

Three Chinese companies have explored opportunities for planting vegetables and other crops in Zanzibar, but none has decided to go ahead. Their major concern appears to be that Zanzibar is too small a market (Pers. comm. 2011). ${ }^{65}$

\section{Rural Energy Projects (under Discussion)}

Several rural energy projects are under discussion. China Dalian International Economic and Technical Cooperation Group won a tender to build a wind farm in Singida (The Citizen 2011). However, although the China Eximbank expressed some interest in financing the project, discussions were still in progress during our visit and no decision had been made. Two hydroelectric power projects (Mpanga and Shuguri) have been under discussion with Chinese companies, but no decisions have been reached. If they go forward, the projects would probably be operated as independent power producers.

\footnotetext{
${ }^{62}$ NGO official, telephone interview, Arusha, Tanzania, September 27, 2011.

${ }^{63}$ Tanzania Investment Centre, “Investments with Chinese Interest from 1990-December 2010,” September 2011.

${ }^{64} \mathrm{He}$ believed that services were poor, corruption was high, the welfare system for workers was overprotective, and foreign investors experience systemic extortion from government officials. Chinese official, interview, September 21, 2011.

${ }^{65}$ Chinese official, interview, Zanzibar, September 26, 2011.
} 


\section{REFERENCES}

Ai, Ping. 1999. "From Proletarian Internationalism to Mutual Development: China's Cooperation with Tanzania, 1965-95," In Agencies in Foreign Aid: Comparing China, Sweden and the United States in Tanzania, edited by Goran Hyden and Rwekaza Mukandala. London: Macmillan Press: 156-201.

Anhui Office of Local Chronicles, 2005-2007, Local Chronicles of Anhui Province. Accessed August 17. www.ahdfz.gov.cn/html/sj_ahsz/.

Arusha Times. 2010. "Tanzania: Special Talents School Opens in Kiteto," September 4. Accessed August 17. www.allafrica.com/stories/201009060760.html.

Bartke, W. 1975. Economic Aid. New York: Holmes and Meier.

Agence de Presse Africaine. 2007. "Tanzania to Host China-Africa Business Forum 1 December," November 6. www.apaphoto.net/spip.php?article46003.

Bräutigam, D. 1998. Chinese Aid and African Development: Exporting Green Revolution. New York: St. Martin's Press.

_.. 2011a. "Chinese Aid Database," American University, Washington, D.C. March.

.2011b. The Dragon's Gift: The Real Story of China in Africa Oxford: Oxford University Press.

Bräutigam, D. and X. Tang. 2009. "China's Engagement in African Agriculture: 'Down to the Countryside,'” China Quarterly December.

CAMC. 2010. "CAMC President Paid a Visit to Tanzanian President Kikwete," March 26, www.camc.com.cn/english/html/xwgg/142240773.html. "CAMCE Signs Tanzania Wami Sugar Plant Project Contract”, May 28, 2010, http://camce.com.cn/en/news/gsxw/1299589638-479.html.

Centre for Chinese Studies. 2012. Evaluating China's FOCAC Commitments to Africa and Mapping the Way Ahead. Report prepared for the Rockefeller Foundation, January.

China Daily. 2008. "Firm Will Grow Rice in Africa," May 9, Accessed August 11. www.chinadaily.com.cn/bizchina/2008-05/09/content 6674352.htm.

China, Ministry of Commerce. 2009. "China-Aided Tanzania Msoga Rural Primary School Started Construction," May 12, Accessed August 16. www.mofcom.gov.cn/aarticle/i/jyjl/k/200905/20090506241588.html.

Chongqing Business Daily. 2009. "Kinds of Food to Make Money Come to Chongqing Enterprises Losing Grain Laos," April 2, Accessed August 6. http://cq.cqnews.net/jixw/zhcj/200904/t20090402_3142349.htm.

Duwayri, M.D. Tran and V. Nguyen. 1999. "Reflections on Yield Gaps in Rice Production: How to Narrow the Gaps". Paper presented at the FAO expert consultation "Bridging the Rice Yield Gap in Asia and the Pacific," Bangkok, Thailand, October 5-7.

Forum on China-Africa Cooperation. 2006. Forum on China-Africa Cooperation Beijing Action Plan 2007-2009, Accessed August 6. www.focac.org/eng/ltda/dscbzjhy/DOC32009/t280369.htm.

—. 2009. Forum on China-Africa Cooperation Sharm el Sheikh Action Plan 2010-2012, Accessed August 11. www.focac.org/eng/ltda/dsjbzjhy/hywj/t626387.htm.

Government of China. 2006. China's African Policy, reprinted at People's Daily Online, Accessed August 6. http://english.peopledaily.com.cn/200601/12/eng20060112_234894.html.

Government of Tanzania, n.d. "Agriculture," Accessed August 16. www.tanzania.go.tz/agriculture.html.

Indian Ocean Newsletter. 2000. October 21, Accessed January 15.

www.ephrem.org/dehai_news_archive/2000/oct00/0179.html.

Information Policy Blog. 2010. "Tanzania Launches First Phase of National Fibre Backbone,” May 29. Accessed August 16. www.i-policy.org/2010/05/tanzania-launches-first-phase-of-national-fibre-backbone.html. 
IPRCC (International Poverty Reduction Center in China). 2011a. "IPRCC Research Group Conducted Field Research in Tanzania," IPRCC Press Release, January 11, Accessed August 6. www.iprcc.org.cn/front/article/article.action?id=2131.

—. 2011b. "Chinese Ambassador to Tanzania Visited IPRCC," March 17, Accessed September 19. www.iprcc.org.cn/front/article/article.action?id=2237.

IPP Media. 2009. "Our Salvation Is in Agriculture_JK," March 11, Accessed August 17. www.mamboafrica.com/mambo2/country/tanzania/the-trading-room/9865Our\%20Salvation\%20is\%20in\%20Agriculture\%20-\%20JK\%2810-\%20Mar\%5C\%2709\%29.html.

- 2011. China-Aided Agricultural Centre in Tanzania Wins Big Applause, April 4. Accessed August 17. www.ippmedia.com/frontend/index.php?1=27746.

Kimboy, F. 2011. "Tanzania: Low Oil Jetty Capacity to Hinder Bulk Imports,” The Citizen (Dar es Salaam), October 11. http://allafrica.com/stories/201110171592.html.

LARRI (Land Rights Research and Resources Institute). 2009. "The State of the Then NAFCO, NARCO, and Absentee Landlords' Farms/Ranches in Tanzania," February 14, Accessed August 16. www.tanzanialandportal.org/index.php?option $=$ com jidownloads\&Itemid $=64 \&$ view $=$ viewdownload \&catid $=4 \& \mathrm{cid}=32$.

Matango, R. 2006. "Mtibwa Outgrowers Scheme: A Model for Small Holder Cane Production in Tanzania” . Paper presented at a United Nations Conference on Trade and Development expert meeting, "Enabling Small Commodity Producers in Developing Countries to Reach Markets," Palais des Nations, Geneva, December $11-13$.

Ogunsanwo, A. 1974. China's Policy in Africa, 1958-1971, Cambridge: Cambridge University Press.

People's Daily. 2001. "China Agrees to Cancel Part of Tanzania's Debt”, July 18. Accessed August 17. http://english.peopledaily.com.cn/200107/18/eng20010718 75242.html.

Reuters. 2010. "Tanzania to Complete Fibre-Optic Link in June," February 3, Accessed August 17. www.africagoodnews.com/infrastructure/ict/1377-tanzania-to-complete-fibre-optic-link-in-june.html.

Tanzania Investment Centre. 2007. "Sisal Expansion,” January-March.

—. 2011. "Investments with Chinese Interest from 1990-December 2010," September.

Tanzania, Ministry of Agriculture. 2001. Agricultural Sector Development Strategy (ASDS).

—. 2009. "Ten Pillars of Kilimo Kwanza," Accessed August 16. www.tzonline.org/pdf/tenpillarsofkilimokwanza.pdf.

Tanzania, Ministry of Foreign Affairs. n. d. "Sino Tanzania Relations: Brief" Department of Asia and Australasia, Tanzania.

Tanzania, Ministry of Foreign Affairs and Ministry of Finance and Economic Affairs. 2008. "Brief on the People's Republic of China in Respect of the State Visit to China by the President of the United Republic of Tanzania, H. E. Jakaya Mrisho Kikwete,” March.

Tanzania, Ministry of Water. n.d. "Chalinze Water Supply Project,” Dar es Salaam, Tanzania.,Accessed October 15. www.maji.go.tz/info/projects.php.

Tanzania, Office of the Prime Minister. 2001. Rural Development Strategy, December.

The Citizen (Dar es Salaam). 2011. “Tanzania: China Group Shows Interest in Singida Farm Project,” March 2. Accessed August 17. www.thecitizen.co.tz/news/3-features/8733-china-group-shows-interest-in-singidafarm-project.html.

USAID. 2008. Tanzania Coastal Management Partnership with the support of the United States Agency for International Development, A Profile of the Wami River Sub-Basin, June, Accessed August 11. http://pdf.usaid.gov/pdf_docs/PNADN794.pdf. 
World Bank. 2011. "High-Level Tanzanian Delegation Visits China to Study Poverty Reduction and Agricultural Reforms," South-South Knowledge Exchange Hub, World Bank, September 28.

Xinhua. 1983. "China to Send Expert Teams for Feasibility Study for Joint Ventures with Tanzania”. August 14.

—. 1996. "Zanzibar President Satisfied with Visit to China," November 19.

_ 2009. "Chinese Envoy Praises Tanzania-China Relations Ahead of Hu Visit", February 11, Accessed August 11. www.accessmylibrary.com/coms2/summary 0286-36684778 ITM.

Xue, H. 2010. "China-Africa Cooperation on Agricultural Development and Economy" Keynote address, ChinaDAC Study Group on Agriculture, Food Security, and Rural Development, Bamako, Mali, April 27-28.

Yu, G. 1970. China and Tanzania: A Case Study in Cooperation Interaction, Berkeley: Center for Chinese Studies, University of California.

- 1975. China's Africa Policy: A Study of Tanzania, New York: Praeger.

ZAYEDESA. 2009. "Project: Self Employment and Entrepreneurship". Accessed December 5. http://zayedesa.org/z_selfempl.html.

Zou, H. 2008. "Chongqing Enterprises Will Go to Africa: Grain," Chongqing Evening News, May 7, www.africawindows.com/html/feizhouzixun/feizhoushangxun/20080507/18350.shtml. 


\section{RECENT IFPRI DISCUSSION PAPERS}

\section{For earlier discussion papers, please go to www.ifpri.org/pubs/pubs.htm\#dp. All discussion papers can be downloaded free of charge.}

1213. The partially liberalized cocoa sector in Ghana: Producer price determination, quality control, and service provision. Shashidhara Kolavalli, Marcella Vigneri, Haruna Maamah, and John Poku, 2012.

1212. Structural change in Argentina, 1935-60: The role of import substitution and factor endowments. Dario Debowicz and Paul Segal, 2012.

1211. Traceability in a supply chain with repeated moral hazard. Alexander E. Saak, 2012.

1210. Managing transition in Yemen: An assessment of the costs of conflict and development scenarios for the future. Clemens Breisinger, Olivier Ecker, Perrihan Al Riffai, Wilfried Engelke, and Abdulmajeed Al-Bataly, 2012.

1209. Bangladesh rice trade and price stabilization: Implications of the 2007/08 experience for public stocks. Paul A. Dorosh and Shahidur Rashid, 2012.

1208. Analyzing intersectoral convergence to improve child undernutrition in India: Development and application of a framework to examine policies in agriculture, health, and nutrition. Rajani Ved and Purnima Menon, 2012.

1207. Branding and agricultural value chains in developing countries: Insights from Bihar, India. Bart Minten, K.M. Singh, and Rajib Sutradhar, 2012.

1206. Costly posturing: Relative status, ceremonies, and early child development in China. Xi Chen and Xiaobo Zhang, 2012.

1205. Should private storage be subsidized to stabilize agricultural markets after price support schemes are removed?: A general equilibrium analysis applied to European reforms. Fabienne Femenia, 2012.

1204. Mapping the contemporary fertilizer policy landscape in Malawi: A guide for policy researchers. Noora-Lisa Aberman, Michael Johnson, Klaus Droppelmann, Eva Schiffer, Regina Birner, and Peter Gaff, 2012.

1203. The economic consequences of excess men: Evidence from a natural experiment in Taiwan. Simon Chang and Xiaobo Zhang, 2012.

1202. The value of customized insurance for farmers in rural Bangladesh. Daniel Clarke, Narayan Das, Francesca de Nicola, Ruth Vargas Hill, Neha Kumar, and Parendi Mehta, 2012.

1201. Gender assessment of the agricultural sector in the Democratic Republic of the Congo. Catherine Ragasa, Annie KinwaMuzinga, and John Ulimwengu, 2012.

1200. Toward an integrated approach for addressing malnutrition in Zambia: A literature review and institutional analysis. Jody Harris and Scott Drimie, 2012.

1199. Review of input and output policies for cereal production in Bangladesh. Hemant Pullabhotla and A. Ganesh-Kumar, 2012.

1198. Onset risk and draft animal investment in Nigeria. Hiroyuki Takeshima, 2012.

1197. Farmer groups, input access, and intragroup dynamics: A case study of targeted subsidies in Nigeria. Lenis Saweda Liverpool-Tasie, 2012.

1196. Does food security matter for transition in Arab countries? Jean-Francois Maystadt, Jean-Francois Trinh Tan, and Clemens Breisinger, 2012.

1195. Agriculture, income, and nutrition linkages in India: Insights from a nationally representative survey. Priya Bhagowalia, Derek Headey, and Suneetha Kadiyala, 2012.

1194. Targeted subsidies and private market participation: An assessment of fertilizer demand in Nigeria. Lenis Saweda Liverpool-Tasie, 2012.

1193. Mineral resources and conflicts in the Democratic Republic of the Congo: A case of ecological fallacy. Giacomo De Luca, Jean-Francois Maystadt, Petros G. Sekeris, John Ulimwengu, and Renato Folledo, 2012.

1192. What dimensions of women's empowerment matter most for child nutrition?: Evidence using nationally representative data from Bangladesh. Priya Bhagowalia, Purnima Menon, Agnes R. Quisumbing, and Vidhya Soundararajan, 2012.

1191. Unattended but not undernourished: Young children left behind in rural China. Alan de Brauw and Ren Mu, 2012. 


\section{INTERNATIONAL FOOD POLICY}

RESEARCH INSTITUTE

www.ifpri.org

IFPRI HEADQUARTERS

2033 K Street, NW

Washington, DC 20006-1002 USA

Tel.: +1-202-862-5600

Fax: +1-202-467-4439

Email: ifpri@cgiar.org 